\title{
CONSUMPTION OF ORGANIC PRODUCTS IN ROMANIA IN 2020
}

\section{Luiza Zapucioiu ${ }^{1}$}

\begin{abstract}
As a production system, organic agriculture is linked to less intensive practices. Therefore, its main mission is to produce much more ecological products and services than conventional agriculture. It does not use potentially harmful technologies technological approaches and inputs of intensive agriculture, as are pesticides, synthetic nitrogen fertilizers, GMO crops or veterinary and anthelmintic antibiotics, thus reducing environmental and health risks. Consumption of organic products has been increased in last couple decades in Romania. The main paper goal is to analyse the consumers' attitudes toward the organic products, primarily agri-food products, as well as their buying motives and satisfaction with the existing offer in the national market. Used methodological framework contains an online survey conducted in the first half of 2020. Among achieved results next has been underlined that majority of respondents consume organic products so often. Their first choice is organic vegetable products, followed by organic animal products and in some cases organic cosmetics.
\end{abstract}

Key words: organic agriculture, organic products, consumption, Romania.

JEL²: Q5, Q15

\section{Introduction}

Organic agriculture is an area continuously expanding. Mentioned trend results from the need of consumers for organic products, as they become more and more aware and interested in the benefits brought by consuming these products (MADR, 2014).

Organic farming has deep historical roots, especially as a practical occupation. All the great human civilizations, such are Mesopotamian, Arab, Greek, Roman, Chinese, etc., have been built a prosperous, but non-polluting agriculture that was not based on chemical fertilizers and synthetic pesticides (Toncea et al., 2016). These ancient practices were based only on hard work, dexterity and logical thinking, stimulating the productivity of the key agricultural components such are soil, plants, animals, etc.

European Commission illustrates organic agriculture as a different agricultural system based on several aspects. It supports renewal of resources and recycling,

1 Luiza Zapucioiu, M.A, Ph.Ds., Bucharest University of Economic Studies, Piata Romana no. 6, 010374 Bucharest, Romania, Phone: +40 784838 325, E-mail: luiza.zapucioiu25@gmail.com

2 Article info: Original Article, Received: 21 January 2021., Accepted: $5^{\text {th }}$ March 2021. 
returning soil to nutrients, with special care for biodiversity and the use of natural foods. This kind of agriculture bans the use of artificial pesticides, fungicides, herbicides, chemical fertilizers, growth hormones, antibiotics, etc. Also, farmers use certain organic methods of production that maintain the ecosystem clean and reduce the level of pollution (Vlahovic et al., 2019).

Organic agriculture represents the sector with a huge prospect for Romania. It benefits from appropriate developmental conditions, such as fertile soil and low level of pollution. Comparing with economically developed countries, that have implemented super-intensive agricultural technologies based on agro-chemicals use, Romania shows a very promising background for organic farming (MADR, 2014).

In line to increased consumption of organic products during the previous period in Romania, paper analyses the consumer attitudes towards the organic food, as well as their purchase motives and satisfaction to offered organic and organic agro-food products in national market. It has been underlined that there is a strong link between increase in consumption of organic products and increase in level of education. Opposite to stereotype that consumers of organic products bring the irrational fear, or the lack of ability to figure out the technological evolution, it seems that highly trained and educated persons usually claims toward the critical assessment of knowledge that they more prefer to consume the "green" food (Lawrence et al., 2001).

\section{Methodological framework}

The used methodology considers the online survey based on questionnaire that was done through the social networks during the period February - June 2020. Survey was involved 306 respondents that answer to 18 previously determined questions. Other applied methods are comparative analysis, desktop research, intensive literature review, method of deduction, etc. Responds to the questionnaire was visually presented in proper manner.

As the aim of survey was to show the key preferences and attitudes of consumers regarding the use of organic products (e.g. awareness of advantages for health and environment, price, frequency of consumption, etc.), obtained results could serve as the base for profiling the consumers, while it helps in creating future strategies and scenarios toward the organic market. There are few research objectives trying to identify: 1) Role of organic products in line to overall concerning for healthy food; 2) Reasons why people choose the organic products; and 3) Usual behaviour of the organic products' consumers. 


\section{Research and results}

Organic farming and consumption of organic products in Romania are still under the developing process. More and more people are adhering to a healthy lifestyle, being aware the benefits of organic products and choosing to consume them over the conventional products. Organic agriculture is a sustainable approach. Contrary to conventional agriculture, it is not turned to individual high-impact activities, while overall productivity compared to conventional agriculture heavily relies on available climate and soil conditions.

In Romania, the consumption of organic products is mainly based on products of vegetable and animal origin that are consumed weekly. Their advantages are usually seen in brought quality and overall, primarily health benefits. In other words, consumers usually consider organic products as very clean, while they can improve their health condition. They tend to be purchased even if the products' price is higher than a price of conventional products. Besides, there is a strong sociological factor recognised in consumers' decision to support local farmers. Meanwhile, actual transition from intention to real purchase remains triggered by socio-demographic factor and income level, as the majority of consumers of organic products belong to the group of urban people with an average salary.

Figure 1. Respond to the question - Do you consume organic products?

\begin{tabular}{lcc} 
Yes & 248 & $81 \%$ \\
\hline Not & 30 & $9.8 \%$ \\
I do not know & 28 & $9.2 \%$ \\
\hline Total answers & 306 &
\end{tabular}

Source: Zapucioiu, 2020.

In line to domination of positive answers (Figure 1.), it could be concluded that the organic products in Romania are used more than it seems to be.

The fast growth of organic food industry and impact of organic agriculture, increase the consumers' trust in organic products, focusing to potential health and environmental risks of conventional food production practices. For example, previous food accidents as are mad cow disease or foot and mouth disease in animal production or traces of pesticides, antibiotics and fertilizer found in plant food products decreased the consumer trust in commonly or traditionally produced food products. 
So a lot of consumers choose "green" products in line to their health and nutrition advantages. In previous years, researchers have compared organic with conventional food respecting their nutritional structure. Some analysis has showed that organic production affects the growth of nutrients, especially organic acids and polyphenolic compounds i.e., antioxidants, which have proved health benefits for human (Winter, Davis, 2006).

Figure 2. Respond to the question - How often do you consume organic products?

\begin{tabular}{lcc} 
Daily & 58 & $19 \%$ \\
\hline Weekly & 125 & $40.8 \%$ \\
\hline Monthly & 95 & $31 \%$ \\
\hline Notat all & 28 & $9.2 \%$ \\
\hline Total answers & 306 &
\end{tabular}

Source: Zapucioiu, 2020.

It is interesting that almost $60 \%$ of respondents (Figure 2.) consume organic products relatively very often (on daily basis or weekly), showing that they really care in some segment about the quality of their nutrition. Encouraging is the fact that relatively negligible group within the surveyed population (less than 10\%) does not consume this kind of products at all, showing that generally people are aware of benefits organic food products offer.

Food consumption affects the most powerful environmental implications. Majority of them appears in sectors of production and processing, as people individually show different features related to food, such are: consuming specific food-stuff; demanding various food products and food-related areas (e.g. imported or national products); procuring and preparing food on different ways; or generating divergent level of organic and packaging waste, etc. Concerning related to upcoming decades are directed to expected significant grow in food consumption, therefore this issue initiate even today the necessity to look over for sustainable ways of producing and consuming agri-food products (Buko, 2009). So often, analytical mechanism for quantification of environmental implications of food consumption are not sufficiently developed, as there are usually lack of quality data or they could be hardly linked to individual behaviour. 
Figure 3. Respond to the question - What category of organic products do you consume?

\begin{tabular}{lcc} 
Products of animal origin (meat, milk, eggs, etc.) & 220 & $39.3 \%$ \\
\hline Vegetable products (fruits, vegetables, cereals) & 245 & $43.8 \%$ \\
\hline Cosmetics & 58 & $10.4 \%$ \\
\hline Household cleaning products & 31 & $5.5 \%$ \\
\hline Others & 6 & $1.1 \%$ \\
\hline Total answers & 560 &
\end{tabular}

Other answers

- I do not consume

- I do not consume

- No category

- not

- Not necessary

- Clothes

Source: Zapucioiu, 2020.

The largest part of consumed organic products belongs to the category of animal and plant products (Figure 3.), showing that people among every day supplies consider the food as the item that affects the individual health and environmental issues the most.

According to above mentioned, adequate respond at supply side of organic sector of agri-food production in Romania and surrounding countries could be seen through the next facts: Currently Romania dominates in organic fruit growing with around 5,900 ha, while in the structure of total areas under organic production, fruit has a moderate share of around $2.6 \%$. It is followed by Bulgaria with 4,000 ha and Hungary with 2,200 ha under organic fruit plantations. It was recorded that the most rapid growth in organic fruit growing appeared in Bulgaria in 2016., when there were available almost 7,700 ha.

Organic production of vegetables could be conducted in open fields, in protected areas (greenhouses), or in small garden cultivation. The largest capacities for organic veggie production are in Hungary, around 2,000 ha, while it is followed by Bulgaria with 1,800 ha and Romania with 1,200 ha. The most highest increase in available area for organic vegetables production was registered in Bulgaria in 2016., when it reached almost 4,000 ha (Vlahovic et al., 2019). 
Figure 4. Respond to the question - What kind of organic products do you buy?

\begin{tabular}{lcc} 
Romanian & 237 & $77.5 \%$ \\
\hline Import & 69 & $22.5 \%$ \\
\hline Total answers & 306 &
\end{tabular}

Source: Zapucioiu, 2020.

Related to this question (Figure 4.), it is obvious that consumers highly prefer the domestic over the imported products.

In the last several years, Romanians are adapting to much healthier and cleaner lifestyle, which includes the consuming of organic products. Majority of these products are produced in Romania and purchased at national market showing that people have a wish to support the local entrepreneurial activities. Mentioned strivings demonstrate the possible interestingness of national organic sector, defining its potential for expansion.

Comparing the Romania with Serbia, it is obvious that it is involved much deeper into the organic production, as the number of organic certificate holders is more than 26,000, compared to 285 in Serbia. The assortment of organic agri-food products gained in both countries is similar. In Romania it includes: products gained from processing of cow and sheep milk as are cheese, butter, sour cream, etc., products that derive from soybean and sunflower processing, different types of pastry and bakery products, cereal products, herbal tea, juices, berries, bee products, pork meat products and wine. In Serbia it considers: grains and buckwheat products, processed chokeberry, macrobiotic food gained from soybean, dried fruits, mushrooms, alcoholic beverages, medicinal herbs and spices, jams and juices, tea, fresh and processed vegetable and fruit, meat and meat products, and dairy products. Related to consumption of produced organic products, up to $80 \%$ of Romanian production is exported, while up to $90 \%$ of Serbian production is sent to EU (Jeločnik et al., 2014).

Related to Figure 5., it is obvious that most of the shopping of organic products in Romania is done in retail (over 55\% in supermarkets or hypermarkets). Contrary to that, less than $10 \%$ of respondents are comfortable to purchase these products online. 
Figure 5. Respond to the question - Where do you usually buy organic products?

\begin{tabular}{lcc} 
Supermarket / hypermarket & 242 & $56 \%$ \\
\hline Specialty stores & 82 & $19 \%$ \\
\hline Profile fairs & 77 & $17.8 \%$ \\
\hline Online & 31 & $7.2 \%$ \\
\hline Total answers & 432 &
\end{tabular}

Source: Zapucioiu, 2020.

In line to Figure 6., it could be seen that expected or confirmed products quality and gained benefits are the best recommendations for its purchase (almost $78 \%$ of respondents). It is interesting that less than $2.5 \%$ of respondents do not considers purchase of organic products as a trendy activity.

Figure 6. Respond to the question - During the purchase what determines you to choose organic product over conventional one?

\begin{tabular}{|c|c|c|}
\hline The quality & 222 & $43.8 \%$ \\
\hline The benefits brought & 173 & $34.1 \%$ \\
\hline The price & 34 & $6.7 \%$ \\
\hline Recommendation (friends, relatives, doctor, etc.) & 66 & $13 \%$ \\
\hline The trend & 12 & $2.4 \%$ \\
\hline Total answers & 507 & \\
\hline
\end{tabular}

Source: Zapucioiu, 2020.

With each buying, consumer is taking the reasons and satisfaction contained in offered organic food products. After certain level of comparing of Croatian, Bosnian and Slovenian markets it comes to fact that respondents in observed territories show positive attitude to the organic food. As the most significant reason for purchasing organic food products in Croatia and Slovenia are noted their health and environmental effects, while in Bosnia prevails the belief of returning back to nature, health values and safety umbrella of organic agri-food products (Cerjak et al., 2010). 
Figure 7. Respond to the question - What is the price you are willing to pay for organic product?

\begin{tabular}{|c|c|c|}
\hline $10 \%$ more than the price of a conventional product & 106 & $=$ \\
\hline $20 \%$ more than the price of a conventional product & 135 & $44.1 \%$ \\
\hline $50 \%$ more than the price of a conventional product & 36 & $11.8 \%$ \\
\hline Double the price of a conventional product & 11 & $3.6 \%$ \\
\hline $\begin{array}{l}\text { I am not willing to pay a higher price for an organic } \\
\text { product. / I prefer to buy a conventional product at } \\
\text { a lower price. }\end{array}$ & 18 & $5.9 \%$ \\
\hline Total answers & 306 & \\
\hline
\end{tabular}

Source: Zapucioiu, 2020.

Survey results show that people are generally ready to pay up to the $20 \%$ more (almost $80 \%$ of respondents) for the organic products (Figure 7.). Very small group does not care about the products price, being ready to pay $50 \%$ more or even double price for certain organic product.

Organic products are considered as premium products by the majority of population. Some studies have tested the level of price that consumers are ready to pay. Gained results show that in USA and EU during the organic products purchase they are prepared to pay a premium (upgrade to active price of conventional products) up to $40 \%$ (Vapa Tankosic et al., 2018). Some analysis notes that interest for organic food-products is going to be based more on a differential price, because people prefer good alternatives that are better for their health. The tendency for organic products demand is going to be reduced, primarily affected by their price. Most often, the purchasing barrier for organic products is their high prices and market availability linked to supply inconsistencies (Yiridoe et al., 2005).

Majority of respondents (almost 64\%) associates the organic agri-food products with products gained at the small farms, while almost the $30 \%$ enjoy the organic agri-food products as environmentally friendly products (Figure 8.).

In terms of health advantages, the consumption of organic products has been proved to expose consumers to fewer pesticides' risk linked to human diseases, showing that organic agriculture has less environmental implications than conventional approaches (Forman et al., 2012). 
Figure 8. Respond to the question - What is the main idea you associate with organic agri-food product?

\begin{tabular}{lcc} 
Environmentally friendly product & 87 & $28.4 \%$ \\
\hline Product from small farmers, from the country & 195 & $63.7 \%$ \\
\hline Durable product & 14 & $4.6 \%$ \\
\hline Others & 10 & $3.3 \%$ \\
\hline Total answers & 306 &
\end{tabular}

\section{Other answers}

- Healthy products with few harmful factors

- Health, taste

- Fewer E's

- Healthy

- Ecological certification

- eco product without additives

- not

- The quality of macronutrients

- Product with a much higher quality

- There are no agro eco products

Source: Zapucioiu, 2020.

Available studies have not indicated any adverse or disease effects linked to the organic products consumption. Although organic products usually has a higher price, certain farming studies show that production costs can be competitive and yields comparable to those one gained in conventional farming. Thus, health and environmental effects of organic products and organic agriculture encourage buyers to choose "green" products.

Figure 9. Respond to the question - How do you assess the value for money of organic agri-food products?

\begin{tabular}{lcc} 
Correct & 239 & $78.1 \%$ \\
\hline Incorrect & 67 & $21.9 \%$ \\
\hline Total answers & 306 & \\
\hline
\end{tabular}

Source: Zapucioiu, 2020. 
The most of respondents (more than 78\%) consider the quality-price ratio of organic agri-food products as correct (Figure 9.). Mentioned explains that buyers are interested more in health benefits and environment safeness that that are contained in purchase of organic products.

Figure 10. Respond to the question - What is your favourite brand of organic products?

\begin{tabular}{lcc} 
Napolact & 172 & $56.2 \%$ \\
SanoVita & 94 & $30.7 \%$ \\
\hline DM & 22 & $7.2 \%$ \\
\hline Others & 18 & $5.9 \%$ \\
Total answers & 306 &
\end{tabular}

Source: Zapucioiu, 2020.

Many Romanians more prefers the Romanian brands (Figure 10.), supporting on that way national economy.

Figure 11. Respond to the question - In your opinion, what are the benefits of consuming organic products?

\begin{tabular}{lcc} 
They are healthier for the body & 267 & $51.8 \%$ \\
They taste better & 106 & $20.6 \%$ \\
\hline They do not contain pesticide residues & 103 & $20 \%$ \\
\hline They are rich in antioxidants & 54 & $1 \%$ \\
\hline Others & 515 &
\end{tabular}

Source: Zapucioiu, 2020.

The dominant benefit of organic products consuming is their health effect to the human body (more than 50\% of respondents), (Figure 11.).

The general belief in consuming organic products is mainly the much better quality of naturally gained products. Quality is more important factor than the gained yields and overall volume of production. Decrease in yields in organic farming is compensated by their biggest prices, as consumers are willing to pay more money for safer, healthier and environmentally friendly products (Andrei et al., 2015). 
The majority of respondents (almost 58\%) consider recycled paper/cardboard as the best fitted material for packaging of organic products (Figure 12.). Contrary to that the metal is definitely among the unwanted materials used for the packaging $(0,3 \%)$.

Figure 12. Respond to the question - What material you consider the best for the packaging of organic products?

\begin{tabular}{lcc} 
Recycled paper / Cardboard & 177 & $57.8 \%$ \\
\hline Biodegradable plastic & 71 & $23.2 \%$ \\
\hline Glass & 52 & $17 \%$ \\
\hline Metal & 1 & $0.3 \%$ \\
\hline Others & 5 & $1.6 \%$ \\
\hline Total answers & 306 &
\end{tabular}

Source: Zapucioiu, 2020.

Sustainable development is a concept developed over the several decades, while its implementation represents a complex issue requiring long term and continuous public support. Circular economy is a kind of newly born form of economy, i.e. model of economic-environmental development. That is why the package of the organic product has a so big importance. Model of circular economy is approach of sustainable production that is focused on a broader, innovation-based products methodology links to multiple life-cycle of products (Banaite, 2016).

During the last several decades consumption of plastic has become a matter of big concern, as globally is produced almost 200 million tons of plastic annually, while $96 \%$ of them is not even recycled. Significant part of this volume goes for packaging and its used only once, while then goes in landfills (big issue are plastic bags as a waste). Unfortunately, plastic is not biodegradable material and represents a serious danger for soil, oceans and biodiversity as well. It is especially dangerous for the oceans' flora and fauna. This problem is widely recognized by many countries (Buko, 2009).

Figure 13. Respond to the question - What is your gender?

\begin{tabular}{lcc} 
F & 244 & $79.7 \%$ \\
\hline M & 62 & $20.3 \%$ \\
\hline Total answers & 306 & \\
\hline
\end{tabular}

Source: Zapucioiu, 2020. 
Dominant group of examinees are female (almost 80\%), (Figure 13.), potentially showing that female persons are much more interested in consuming of organic products.

Figure 14. Respond to the question - Where do you live?

\begin{tabular}{lcc} 
Urban & 219 & $71.6 \%$ \\
\hline Rural & 87 & $28.4 \%$ \\
\hline Total answers & 306 &
\end{tabular}

Source: Zapucioiu, 2020.

The most of respondents (over the 71\%) are living in urban settlements (Figure 14.), meaning that urban way of life fosters the urban population to be more oriented to practicing of natural principles.

Figure 15. Respond to the question - The age group you belong to?

\begin{tabular}{lcc}
$18-25$ years & 202 & $66 \%$ \\
\hline $26-35$ years & 49 & $16 \%$ \\
\hline $36-45$ years & 18 & $5.9 \%$ \\
\hline Over 45 years & 37 & $12.1 \%$ \\
\hline Total answers & 306 &
\end{tabular}

Source: Zapucioiu, 2020.

Majority within the examined population $(66 \%)$ are younger than 25 years (Figure 15.), while the largest group of respondents involve the persons with higher education (almost 88\%), (Figure 16.).

Figure 16. Respond to the question - What is your education level?

\begin{tabular}{lcc} 
Secondary education & 38 & $12.4 \%$ \\
\hline Higher education & 268 & $87.6 \%$ \\
\hline Total answers & 306 &
\end{tabular}

Source: Zapucioiu, 2020.

Thus, education definitely has a pronounced impact. Some analysis shows that the group of persons consuming organic food is enlarging, both in line to basic and scientific education (Lockie et al., 2002). 
Regarding the occupation, the majority of respondents are employed (49\%) or still at university studies (over 41\%), (Figure 17.).

Figure 17. Respond to the question - What is your occupation?

\begin{tabular}{lcc} 
Student & 127 & $41.5 \%$ \\
\hline Employee & 150 & $49 \%$ \\
\hline Retired & 7 & $2.3 \%$ \\
\hline Freelance & 22 & $7.2 \%$ \\
\hline Total answers & 306 &
\end{tabular}

Source: Zapucioiu, 2020.

Figure 18. Respond to the question - What is your net monthly income?

\begin{tabular}{lcc} 
Under 1000 lei & 56 & $18.3 \%$ \\
\hline $1000-2000$ lei & 72 & $23.5 \%$ \\
\hline $2000-3000$ lei & 88 & $28.8 \%$ \\
\hline Over 3000 lei & 90 & $29.4 \%$ \\
\hline Total answers & 306 &
\end{tabular}

Source: Zapucioiu, 2020.

Related to available income (Figure 18.), observed groups are well balanced (Figure 18.), showing that no matter to monthly level of the net income $\left(1,000\right.$ - over 3,000 lei $\left.^{3}\right)$ people that are willing to by the organic product they will make a purchase in certain volume. So, income surely affects the purchase but not enough to be confirmed that the rise of level of available income significantly affects the number of organic food consumers. So, it could be noted that while the premium related to organic products may make them less cost-effective for persons with moderate revenues, they are not less interested in consuming "green" products.

\section{Conclusion}

The gained survey results show that majority of respondents consume organic products, usually on weekly basis. Consumers of organic products are mostly turned to organically produced plants (fruits, or vegetables), then products of animal origin

3 Lei $=$ RON (Romanian currency). 
(meat, milk and processed products), while some choose organic cosmetics. The main purchase destination is the supermarket, as it offers the large assortment of products. Some of persons are directed to specialized stores. The main reason that drives the purchase of organic products is linked to their health benefits, better taste and quality, as they are being considered premium products.

The growth in organic sector is usually guided both by higher incomes that could be gained and by the involved health and food safety features, affecting the constant expansion and good position of the niche-market for the "green" food products. So, assumption that organic food is usually much expensive comparing to conventional one, so that only rich people or persons that are largely aware of health or environment implications are buying these products is just partly valid. Price and available income level for sure have the influence on organic consumption, but this influence is not so pronounced as general stereotypes.

Although consumers turned to organic products express stronger sense and motivations related to issues of environment, biodiversity, animal welfare, biotechnology, etc., their views are not completely different from persons that are non-organic consumers. Even though the majority of consumers show a good attitude to organic food, the actual transition from purchase intention to moment of purchase remains triggered by socio-demographic variables and income level.

\section{References}

1. Andrei, J., Popescu, C., Ion, R., Dobre, I. (2015). From conventional to organic in Romanian agriculture: Impact assessment of a land use changing paradigm. Land Use Policy, 46:258-266.

2. Banaite, D. (2016). Towards circular economy: Analysis of indicators in the context of sustainable development. Social Transformation in Contemporary Society, 4(9):142-150.

3. Buko, A. (2009). Environmental citizenship for sustainable consumption. Unpublished Master's thesis, University of Twente, the Netherlands, retrived at: https://essay.utwente.nl/60267/, 15 ${ }^{\text {th }}$ February 2021.

4. Cerjak, M., Mesić, Ž., Kopić, M., Kovačić, D., Markovina, J. (2010). What motivates consumers to buy organic food: Comparison of Croatia, Bosnia Herzegovina, and Slovenia. Journal of Food Products Marketing, 16(3):278-292.

5. Forman, J., Silverstein, J. (2012). Organic foods: Health and environmental advantages and disadvantages. Pediatrics, 130(5):e1406-e1415. 
6. Jeločnik, M., Ion, R. A., Jovanović, M., Popescu, C. G. (2015). Has organic farming potential for development? Comparative Study in Romania and Serbia. Procedia Economics and Finance, 22:268-276.

7. Lawrence, G., Norton, J., Vanclay, F. M. (2001). Gene technology, agri-food industries and consumers. In: Hindmarsh, R., Lawrence, G. (Eds.) Altered Genes II: The Future?, Scribe, Melbourne, Australia, pp. 143-172.

8. Lockie, S., Lyons, K., Lawrence, G., Mummery, K. (2002). Eating 'green': Motivations behind organic food consumption in Australia. Sociologia ruralis, 42(1):23-40.

9. MADR (2014). Agricultura ecologica. Publicaţia tematică, no. 4, vol. II, Ministry of Agriculture and Rural Development (MADR), Bucharest, Romania, retrieved at: http://madr.ro/docs/dezvoltare-rurala/rndr/buletine-tematice/PT4. pdf, 18 ${ }^{\text {th }}$ December 2020.

10. Toncea, I., Simion, E., Ionita, G., Alexandrescu, D., Toncea, V. A. (2016). Manual de Agricultura Ecologica. Suport de Curs, PNDR, Bucharest, Romania, retrieved at: http://agriculturadurabila.ro/wp-content/uploads/2016/06/manual. pdf, $3^{\text {rd }}$ January 2021.

11. Vapa Tankosic, J., Ignjatijevic, S., Kranjac, M., Lekic, S., Prodanovic, R. (2018). Willingness to pay for organic products on the Serbian market. International Food and Agribusiness Management Review, 21(6):791-801.

12. Vlahović, B., Užar, D., Škatarić, G. (2019). Comparative Analysis of Organic Food Markets in the Republic of Serbia and the Neighbouring Countries. Contemporary Agriculture, 68(1-2):34-42.

13. Winter, C. K., Davis, S. F. (2006). Organic Foods. Journal of food science, 71(9):R117-R124.

14. Yiridoe, E. K., Bonti Ankomah, S., Martin, R. C. (2005). Comparison of consumer perceptions and preference toward organic versus conventionally produced foods: A review and update of the literature. Renewable agriculture and food systems, 20(4):193-205.

15. Zapucioiu, L. (2020). Studiu privind consumul de produse agroecologice în România. Unpublished Master Thesis, ASE, Bucharest, Romania. 